\title{
Fiber Dimension and Derivatives Value of Sugar Palm Frond in Various Positions
}

\author{
Fatriani $^{1}$, Banjarbaru ${ }^{2}$ \\ ${ }^{1}$ Faculty of Forestry, University of Lambung Mangkurat, Banjarbaru, Indonesia \\ ${ }^{2}$ Ministry of Research, Technology and Higher Education, Faculty of Forestry, University of Lambung Mangkurat, Banjarbaru, Indonesia
}

\section{Email address:}

Fatriani.unlam@yahoo.com (Banjarbaru)

\section{To cite this article:}

Fatriani, Banjarbaru. Fiber Dimension and Derivatives Value of Sugar Palm Frond in Various Positions. Agriculture, Forestry and Fisheries. Vol. 6, No. 2, 2017, pp. 66-68. doi: 10.11648/j.aff.20170602.13

Received: March 16, 2017; Accepted: March 24, 2017; Published: April 1, 2017

\begin{abstract}
This study aimed to analyze the dimensions of fiber and its derivatives in order to utilize as an alternative material of pulp and paper making. Dimensions of fiber include fiber length, fiber diameter, lumen diameter, and cell wall thickness; the values of derivatives studied were runkell ratio, felting power, muhlstep ratio, flexibility ratio, and coefficient of rigidity. Sugar palm frond came from Pingaran Village, Astambul District, Banjar Regency, South Kalimantan. The results show the length of fiber is included in fiber quality class III, Runkell ratio Value, Muhlstep ratio value, and the flexibility ratio value of fiber quality class I, felting power value of fiber quality class IV, Coefficient of Rigidity value of fiber quality class II. Overall fibers produced are included in fiber quality class II with a score of 450. Based on the value of fiber dimension and fiber dimension derivative, the fiber of sugar palm can be used as an alternative raw material for pulp and paper making.
\end{abstract}

Keywords: Sugar Palm Frond, Dimensional Fiber and Its Derivatives, The Quality of the Fiber, Pulp and Paper

\section{Introduction}

Industrial Plantation Forest Development and Community Plantation Forest are encouraged in order to reduce wet tropical forest destruction and compensate the supply of raw material both for building materials as well as for the pulp and paper industry.

Type of wood that is usually used on the construction of industrial plantation forest of paper pulp is a fast-growing species such as Acacia mangium, Eucalyptus sp, Gmelina arborea, Pinus.

Although forest plantation development has been done, but it needs to develop and increase the productivity of both natural forests and plantations themselves, because there are many potential forest plantations and natural forests which are not maximized in its utilization.

One of the natural forests which is not maximized in its utilization is Sugar palm plant species, especially the fiber in its frond, in the framework of development and construction for the utilization of Sugar palm plants it requires nature knowledge associated with pulp and paper.

Related to the above description, this study aimed to gain information of fundamental characteristics of Sugar palm plants as a material production of fiber for pulp and paper.

The basic characteristics studied are the dimensions of the fiber and its derivatives, in order to obtain quality of sugar palm fiber due to the plant development as raw material for pulp and paper.

\section{Methodology}

\subsection{Time and Location of Study}

The study was conducted at the Laboratory of Forest Products Technology, Faculty of Forestry, University of Lambung Mangkurat, Banjarbaru for 6 months from July to December 2016.

\subsection{Materials and Devices of Study}

Materials and tools used in this study were Sugar palm plant from Pingaran Village of Astambul District of Banjar Regency, South Kalimantan, distilled water, hydrogen peroxide, glacial acetic acid, safrani, and glycerin. The equipments used were a saw, plastic for sample, microtome, loupe, object glass, microscope, pipette, and glass lid. 


\subsection{Procedure of Study}

There were two fronds used and from every frond it was taken three parts, namely the base, middle and tip. The base was taken $5 \mathrm{~cm}$ from the former cutting of the bottom/base of the frond, the tip was taken $5 \mathrm{~cm}$ from the tip of the frond, and the middle part was taken right in the middle of the frond (Ruliati and lempang, 2004).

Observation of fiber dimension was done by making preparation of maceration. Sugar palm frond was made into shale of matchsticks. The shale was heated in a tube containing a solution of hydrogen peroxide and glacial acetic acid in the ratio of $1: 1$, fibers that had been separated were washed with running water from the faucet and then stained with safranin fibers that had been dyed poured in an object glass that beforehand had been poured by glycerin. The fiber was spread evenly and then covered with a glass lid. After that the preparations were ready to be observed under a microscope. The parameters of observation for fiber dimensions were fiber length, fiber diameter, lumen diameter, and cell wall thickness, which would be used to get the value of derivatives of fiber dimensions namely Runkell ratio, felting power, Muhlstep ratio, the coefficient of Rigidity, and flexibility ratio.

\subsection{Data Analysis}

Data of fiber dimension and its derivatives were analyzed in tabulation and description with reference to the assessment criteria for pulp wood characteristics (Anonymous, 1976) as Appendix 2.

\section{Result}

\section{Fiber Dimension}

Fiber Dimension is one of the fundamental characteristics that could be used to select the raw material for pulp and paper production. Fiber Dimension of Sugar palm plant can be seen in Table 1 and 2.

Table 1. Fiber Dimension of Sugar Palm Tree at Various Positions 1.

\begin{tabular}{llllll}
\hline \multirow{2}{*}{ No. } & \multirow{2}{*}{ Repetition } & $\begin{array}{l}\text { Tree 1 (micron) } \\
\text { Base }\end{array}$ & $\begin{array}{l}\text { Middle } \\
\text { Part }\end{array}$ & $\begin{array}{l}\text { Tip } \\
\text { Part }\end{array}$ & Average \\
\hline 1 & Fiber Length & 1214.65 & 1148.86 & 1224.28 & 1195.93 \\
2 & Fiber Diameter & 144.57 & 159.98 & 143.26 & 149.27 \\
3 & Lumen Diameter & 121.92 & 137.94 & 120.25 & 126.70 \\
4 & Cell Wall Thickness & 22.65 & 22.04 & 23.01 & 22.56 \\
\hline
\end{tabular}

Table 2. Fiber Dimension of Sugar Palm Tree at Various Positions 2.

\begin{tabular}{llllll}
\hline \multirow{2}{*}{ No. } & \multirow{2}{*}{ Repetition } & \multicolumn{4}{l}{ Tree 2 (micron) } \\
\cline { 3 - 6 } & & $\begin{array}{l}\text { Base } \\
\text { Part }\end{array}$ & $\begin{array}{l}\text { Middle } \\
\text { Part }\end{array}$ & $\begin{array}{l}\text { Tip } \\
\text { Part }\end{array}$ & Average \\
\hline 1 & Fiber Length & 1301.04 & 1268.37 & 1368.00 & 1312.47 \\
2 & Fiber Diameter & 183.86 & 161.41 & 235.18 & 193.49 \\
3 & Lumen Diameter & 159.02 & 137.36 & 209.85 & 168.75 \\
4 & Cell Wall Thickness & 24.84 & 24.05 & 25.32 & 24.74 \\
\hline
\end{tabular}

Fiber Dimension Derivative

Fiber requirements for raw materials of pulp and paper besides being determined by the length of the fiber it is also determined by the value of fiber dimension derivative. The value of fiber dimension derivative can be seen in Table 3 below.

Table 3. Quantity of Fiber Dimension Derivative.

\begin{tabular}{lll}
\hline \multirow{2}{*}{ Parameter } & Tree & \\
\cline { 2 - 3 } & Tree 1 & Tree 2 \\
\hline Runkell Ratio & 0.04 & 0.04 \\
Felting Power & 8.01 & 6.78 \\
Muhlstep Ratio & 27.95 & 23.94 \\
Flexibility Ratio & 0.85 & 0.87 \\
Coefficient Of Rigidity & 0.15 & 0.13 \\
\hline
\end{tabular}

The flexibility ratio value of tree 1 is 0.85 and tree 2 is 0.87; the both trees belong to class I (Anonymous, 1976). The woods with a high flexibility ratio value are good for the making of pulp and paper.

In Table 4 it is presented the results of scoring of fiber dimension and fiber dimension derivative value to determine the classification of fiber.

Table 4. Score Determination Result Based on fiber dimension and its derivative value.

\begin{tabular}{lll}
\hline \multirow{2}{*}{ Parameter } & \multicolumn{2}{c}{ Score Determination Result } \\
\cline { 2 - 3 } & Tree 1 & Tree 2 \\
\hline Fiber Lenght & 50 & 50 \\
Runkell Ratio & 100 & 100 \\
Felting Power & 25 & 25 \\
Muhlstep Ratio & 100 & 100 \\
Flexibility Ratio & 100 & 100 \\
Coefisien Of Rigidity & 75 & 75 \\
Class / Total Score & II / 450 & II / 450 \\
\hline
\end{tabular}

The total of fiber length and the fiber dimension derivative value either on tree 1 and tree 2 result in fiber quality value of class II with a score of 450 (Anonymous, 1976). From the above data, it can be informed that the fibers of the Sugar palm tree have the potential to produce good pulp.

\section{Discussion}

Based on Table 1 and 2 above it is seen that the fiber lengths of tree 1 and tree 2 are included in the classification of medium fiber length (medium) $=900-1600$ microns, (according to the classification of IAWA), according to Anonymous (1976) the length of the fiber in tree 1 and 2 is included grade 3; the longer the wood fibers the higher the strength of pulp produced, it is due to the fiber length provides field wider contiguity and better webbing among one fiber to another. Fiber length also affects certain characteristics of pulp and paper such as tear resistance, tensile power, and folding power.

Fiber diameter of tree 1 is averagely 149.27 microns and lumen diameter is 126.70 microns while in tree 2, fiber diameter is averagely 193.49 microns, lumen diameter is 168.75 microns,

Fiber wall thickness of tree 1 is averagely 22.56 microns, tree 2 is averagely 24.74 microns; both trees included in 
criteria for quality class III with a thick cell wall but the pulp and paper quality is not good. Thin-walled fibers result in the fibers easily become flat resulting pulp and paper sheet denser and the firmness of broken explosion is better than the thick-walled fibers. To obtain high crack and tear firmness, thick-walled fibers need to be mixed with long fiber and thin-walled with wood fibers of needles or ground leaves after they are processed into pulp for some time (Nurrahman and Silitonga, 1972).

Runkell ratio either on the tree 1 or tree 2 is 12.04 , according to Anonymous (1976), Runkell ratio $<0.25$ including Class I and very good category of pulp and paper quality. Wood for the making of good fiber pulp has small Runkell ratio or equal to 0.25 for having thin cell walls and wide lumen diameter so that the fibers entirely flat on a pulp sheet with very strong bonding among the fibers and felting power; pulp sheet produced has high torn, explosion and tensile firmness (Silitonga et al, 1972).

The value of felting power of tree 1 is 8.01 and tree 2 is 6.78 , the value of felting power is the ratio between the fiber length and the fiber diameter. The value of felting power produced is included in class IV because it is $<40$. The greater the ratio the higher the tear power and the better its fiber felting power is. With high tear power it means that the fiber length is longer as well because in establishing inter-fibers become longer and tear force will be divided into a larger area (Shafi'i and Siregar, 2006).

Muhlstep ratio on tree 1 is 27.95 and tree 2 is 23.94; both trees belong to class I $(<30 \%)$, (Anonymous, 1976). The quantity of Muhlstep ratio affects the density of pulp sheet which will ultimately affect the strength of the pulp produced The smaller the Muhlstep ratio the higher the density of pulp sheet produced with high characteristic strength as well, otherwise the high Muhlstep ratio results in the pulp sheet with low density and low power anyway.

Coefficient of Rigidity tree is 0.15 and tree 2 is 0.13 ; both trees belong to class II (Anonymous, 1976). The value of coefficient Rigidity is the ratio of wall thickness to cell fiber diameter. This ratio shows a negative correlation to the power of length and break (tensile power), it means that the higher the Coefficient of Rigidity the lower the tensile power of the paper, conversely the lower the Coefficient of Rigidity the higher the tensile power of the paper concerned. That is why for the making of pulp should have low Rigidity coefficient.

Flexibility ratio is a ratio of lumen diameter and fiber diameter; this ratio has a parabolic relationship with tensile power. This means that the fiber with high flexibility ratio means the fiber has a thin and easily deformed wall thickness. The ability to change shape leads to the interface between the fiber surface which is more freely resulting in better bonding fibers and will produce pulp sheet with good strength (Shafi'i and Siregar, 2006).

The flexibility ratio value of tree 1 is 0.85 and tree 2 is 0.87; the both trees belong to class I (Anonymous, 1976). The woods with a high flexibility ratio value are good for the making of pulp and paper.

\section{Conclusion}

1. Fiber length measurement result either on tree 1 and 2 is included in fiber quality of class III.

2. Runkell ratio value, Muhlstep ratio value and flexibility ratio value are included in fiber quality of class I.

3. Felting power value is included in fiber quality of class IV.

4. The coefficient of Rigidity including fiber quality class II.

5. Overall fibers produced are included in fiber quality of class II with a score of 450 .

6. Based on the values of fiber dimension and fiber dimension derivative, Sugar palm fiber can be used as an alternative raw material for pulp and paper making.

7. Based on the values of fiber dimension and fiber dimension derivative Sugar palm fiber can be used as raw material for the making of pulp and paper, but to overcome the length of the fiber it can be combined with other types of wood.

8. It needs the study of chemical nature of Sugar Palm due to the making of pulp and paper is also very necessary.

\section{References}

[1] Anonymous, 1976. Vademecuum of Indonesian Forestry. Agriculture Department. General Directorate of Forestry. Jakarta

[2] Haygreen, J. G and J. 1 Bowyer. 1996. Forestry and Wood Science. An Introduction, Translation, Gajah Mada University Press

[3] Nurrahman, A and Silitonga, T. 1972. Fiber Dimension of Some Types of South Sumatra Woods. Reports 2, LPHH, Bogor

[4] Narendra. D. B. 2012. Studies Pulping Processes sheaths Fibers and Fiber Fruit Nipah with Microbiological Methods. Essay. Faculty of Agricultural Technology. Brawijaya University, Malang

[5] Pasaribu. R. A. and A. P. Tampubolon. 2007. Status of Utilization of Wood Fiber Technology for Raw Materials Pulp. Socialization Workshop BPHPS Programs and Activities to Support Needs Wood Pulp Plantation Forest Research and Network

[6] Ruliati. S and M. Lempang. 2004. Physical properties and Teak Wood Anatomy of Muna and South kendari. Journal of Forest Research. Vol 22, No. 4: 231 - 237. Research and Development Center of Forest Products Technology. Bogor

[7] Silitongs, T; Siagian, R and Nurrachman, A. 1972. Wood Fiber Measurement Method in Forest Products Research Institute. Special Publication 12. August, 1972. LPHH, Bogor

[8] Syafii, W and I. Z, Siregar, 2006. Chemical Characteristics and Fiber Dimension of Mangium Wood (Acacia mangium Wild) of three provenances. Journal of Science and Technology Tropical Wood Vol 4, \# 1. Indonesian Wood Research Society

[9] Smook, G. A. 1994. Handbook for Pulp and Paper Technologists Second Ed. Friesen Printers Angus Wilde Publication Inc. Kanada

[10] Wardoyo. A. 2001. Effect of Chemicals in Pulp softening properties Semikimia Flakes Against Acacia mangium wild. Thesis, IPB. Bogor (not published) 